\title{
PROBLEMS AND PROSPECTS OF VEGETABLES GARDENING IN MACHCHHEGAUN: A CASE STUDY
}

\author{
Narayan Prasad Paudyal*
}

\begin{abstract}
Agriculture production contributes 32.60 percent of GDP in which vegetable contribution is 9.7 percent in Nepalese economy. This article tries to find out the conditions and state of vegetable production and productivity, including problems and prospects of Machchhegaun, one of the villages of ward no. 7 of Kirtipur Municipality. This village is good for vegetable production due to suitable climate, good topography, fertile land and market accessibility. Of the total arable land, only 6.9 percent is for vegetable production. However, its yield is higher as compared to other staple food crops like paddy, maize and wheat. This apparently shows that there is higher potentiality of vegetable gardening which can be helpful to fulfill the requirements of vegetables to the growing population of Kirtipur Municipality. However the farmers are facing many problems like that of lacking technical knowledge, lack of improved seeds, fertilizer, agriculture equipments and financials supports.
\end{abstract}

Key Words: Vegetable gardening, landholding, production, income, crops, land.

\section{INTRODUCTION}

The agricultural sector has been a major source of production, income and employment opportunities in Nepal. More than 65 percent of the local population is directly or indirectly involved in agricultural sector (CBS, 2001). Nepalese farmers are partly employed for 3 months in a year and in the rest of the months they remain idle. So, agricultural output is very low (Lamichhane, 1999). In general the method of cultivation is purely manual and labour intensive, and farm holding size is small. Agriculture has provided 24.1 percent of the total employment in urban areas and 85.5 percent in rural areas in 1991 (Bhatta, 2013).

Vegetable gardening is a part of agriculture production. In Nepalese economy, agriculture production contributes 32.60 percent of GDP, in which the share of vegetables is 9.7 percent (Agriculture Statistics of Nepal, 2009). Therefore, vegetable gardening could be significant in this context.

In the year 1972, the vegetable development division in the National Agriculture Research Council (NARC) was established to co-ordinate

* Mr. Paudyal is Reader at Mahendra Ratna Campus, T.U., Tahachal, Kathmandu, Nepal 


\section{PROBLEMS AND PROSPECTS OF..}

research for seed production and development of vegetable crops in Nepal. Similarly the year is 1987 , NARC was given the mandate to carry out agricultural research including vegetable crops. This was the starting phase for modern vegetables cropping in Nepal.

Vegetables are produced in the small and large scales in different parts of the Nation. Small scale vegetable production has been done from kitchen gardening which has helped to supply the daily requirements of the family. The large or commercial vegetable production pockets are concentrated along the highways and near town areas (Ghimire, 1999).

In the urban fringes, vegetable gardening appears as one of the productive enterprises for cash generation. However, vegetable gardening in Nepal for commercial purposes started recently. With the overwhelming population growth, increasing demand for vegetables, awareness of people about vegetables consumption in their daily diet, are some major factors which have diverted the farmers towards vegetables gardening. Even though vegetable gardening are broadly practiced just for self consumption, and this is helpful to provide balanced diet. For a balanced diet, the proportion of vegetable needs per capita per meal is considered to be 45 percent of the total volume of foods (Aguraibo, 1979).

This paper tries to explore the conditions of vegetables gardening of Machchhegaun village located at ward no. 7 of Kirtipur Municipality including the problems faced by the vegetable farmers and prospects of vegetable farming in future.

\section{METHODS AND MATERIALS}

This study is based on primary sources of data. The relevant and available secondary data and information are also used. The field work was carried out in Machchhegaun (ward no. 7) of Kirtipur Municipality. And a total of 55 households were sampled out of total 418 households in the selected ward. The primary data were collected during the field survey by structured questionnaire, interview and field observations. A purposive random sampling method was applied for household survey to collect the primary data. For secondary sources of information, various books, journals and unpublished documents were consulted wherever necessary. Qualitative and quantitative both approaches are used for data analysis. The data gathered from field survey and various data were tabulated and analyzed.

\section{THE STUDY AREA}

Kirtipur is located in the South West area of the district. It is situated at $27^{\circ} 38^{\prime} 37^{\prime \prime}$ to $27^{\circ} 41^{\prime} 36^{\prime \prime} \mathrm{N}$. latitude and $85^{\circ} 14^{\prime} 64^{\prime \prime}$ to $85^{\circ} 18^{\prime} 00^{\prime \prime}$ E latitude. It has 19 wards and covers 1787 hectors of land area. It is bordered by the Chalnakhel VDC to the South, Baghmati 
River to the East, Kathmandu Metropolitan city to the North and Naikap to the West. The study area Machchhegaun is located at ward no. 7 of Kirtipur Municipality.

Figure 1: Location of the Study Area

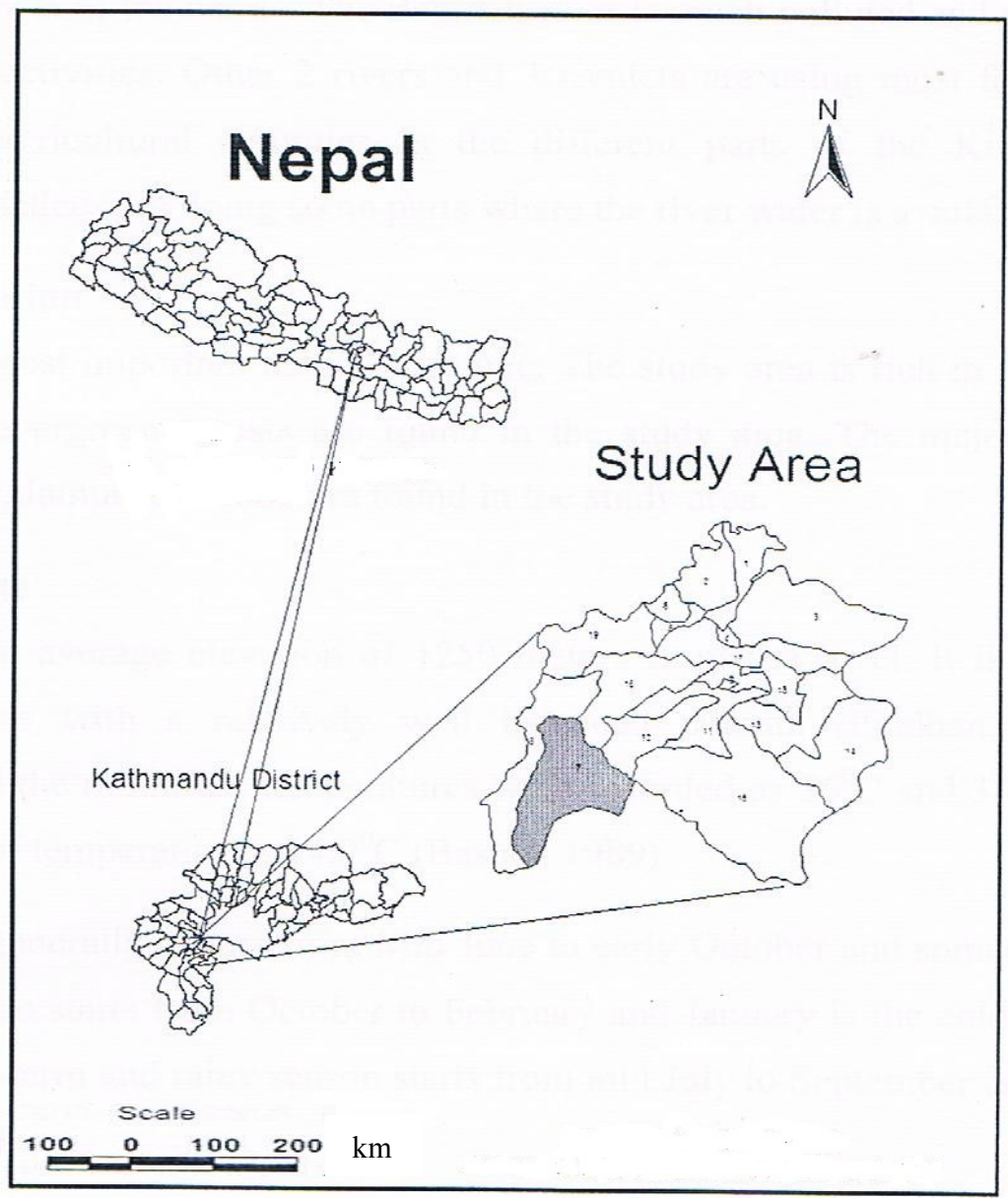

\section{DISCUSSION AND FINDINGS}

\section{LANDHOLDING SIZE OF VEGETABLE GARDENERS}

Land is the most important asset to the farmers of Nepal. The people who have enough land are considered as Jamindar and given a good position in rural society. "Traditionally land is the principal form of wealth, the principal source of economic and political power. Ownership of land has meant a control over a vital factor of production and therefore a position of prestige, affluence and power" (Sapkota, 2003). Landless 
people are considered as Sukumbashi and are treated as labours thereby keeping them in the lowest rank in the society.

Of the total sampled households almost all of them are involved in vegetable gardening either for family income or for family consumption. The distribution pattern of land holding size was uneven in the village i.e. some households possess below 0.15 hectors of land whereas some have more than 0.5 hector ranking differently in the society. However, the field survey has indicated that the total land was not utilized for vegetable production. Although there was good sources of water, due to the lack of proper facilities of irrigation, farmers were compelled to wait for rainfall. The landholding size of the sample households were as follows:

Table 1: Land Holding Size for Vegetable Gardeners

\begin{tabular}{|l|c|c|}
\hline \multicolumn{1}{|c|}{ Land (in ha ) } & No. of Households & Percent \\
\hline Less than 0.15 & 34 & 61.8 \\
\hline $0.15-0.3$ & 9 & 16.4 \\
\hline $0.3-0.45$ & 8 & 14.5 \\
\hline 0.45 above & 4 & 7.3 \\
\hline \multicolumn{1}{|c|}{ Total: } & $\mathbf{5 5}$ & $\mathbf{1 0 0}$ \\
\hline
\end{tabular}

Source: Field Survey, 2013.

\section{Total LANd AREa AND Production OF DifFERENT CROPS}

Farmers of Machchhegaun were engaged for other food crops besides vegetable growing which were staple foods in Nepal. Paddy, maize and wheat were grown in the area; however the production of those crops was less than that of vegetables. So, vegetables production was more important. People were growing paddy in a large area. Of the total arable land, 37.1 percent was used for paddy production which yields $20,000 \mathrm{~kg}$. of per year. Very less area i.e. 6.9 percent was used for vegetable growing which produces $30,000 \mathrm{~kg}$. vegetables annually. The following table shows the crop production area, types of crops and their quantity.

Table 2: Areas and Production of Different Crops

\begin{tabular}{|l|c|c|c|}
\hline \multicolumn{1}{|c|}{ Crops } & Area (in ha) & Percent & Production in kg. \\
\hline Vegetable & 0.6 & 6.9 & 30,000 \\
\hline Paddy & 3.25 & 37.1 & 20,000 \\
\hline Maize & 2.65 & 30.3 & 20,400 \\
\hline Wheat & 2.25 & 25.7 & 4,800 \\
\hline Total: & $\mathbf{8 . 7 5}$ & $\mathbf{1 0 0}$ & $\mathbf{7 5 , 2 0 0}$ \\
\hline
\end{tabular}

Source: Field Survey, 2013. 
Figure 2: Crop Production

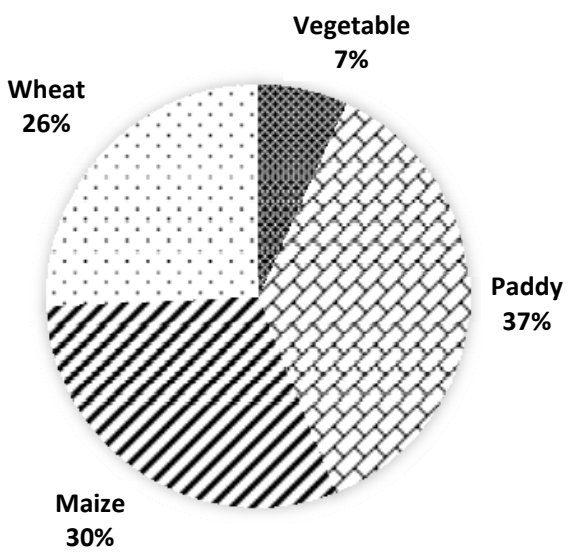

\section{Vegetable Production ANd InCOMe}

Vegetable cropping could be regarded as cash crop to generate income for the farmers. The trend of growing vegetable was found to be increasing in Machchhegaun. Though farmers were engaged to grow vegetables for a long time, vegetable production seemed to be a good source of income only for 8 years in this village.

The level of annual income through production was not even in the village. The level of land distribution affects the level of production. Out of total households, 23 households were earning below 10,000 rupees whereas only 4 households had more than 41,000 rupees in a year. After all, vegetable production had occupied significant position for income generation to the farmers of Machchhegaun (Table 3).

Table 3: Annual Income Level of Farmers by Vegetable Gardening

\begin{tabular}{|c|c|c|}
\hline $\begin{array}{c}\text { Income Level (in } \\
\text { Rs.) }\end{array}$ & No. of Households & Percent \\
\hline Less than 10,000 & 23 & 41.8 \\
\hline $11,000-20,000$ & 17 & 30.9 \\
\hline $21,000-30,000$ & 6 & 10.9 \\
\hline $31,000-40,000$ & 5 & 9.1 \\
\hline 41,000 above & 4 & 7.3 \\
\hline Total: & $\mathbf{5 5}$ & $\mathbf{1 0 0}$ \\
\hline
\end{tabular}

Source: Field Survey, 2013. 
Figure 3: Income Generated through Vegetable Gardening (in percent)

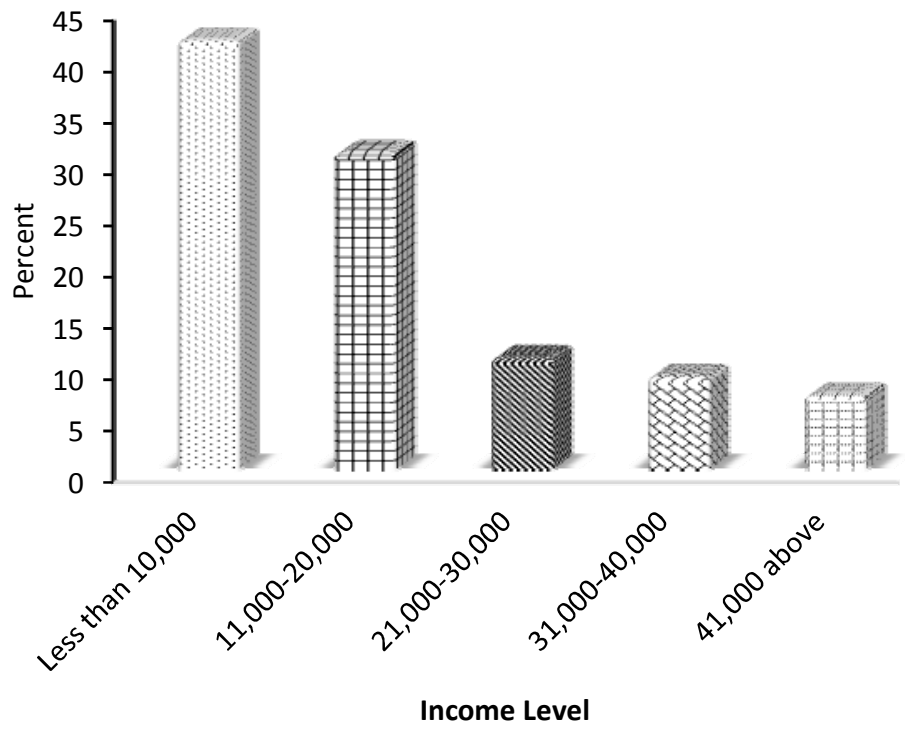

Farmers have grown different vegetables with different earnings. Largely they were growing cauliflower, cabbage and mustard leaf and very less production of bakula. The highest income was generated from cauliflower which was 3,20,000 rupees per annum. However, from bakula they were getting only 3,00,00 rupees by selling $1,000 \mathrm{~kg}$. (Table 4).

Table 4: Types of Vegetable, Production and Income

\begin{tabular}{|l|c|c|c|}
\hline \multirow{2}{*}{$\begin{array}{c}\text { Types of } \\
\text { Vegetables }\end{array}$} & \multicolumn{3}{|c|}{ Vegetable Production in kg. } \\
\cline { 2 - 4 } & Production in kg. & Price per kg. & $\begin{array}{c}\text { Amount (in } \\
\text { Rs.) }\end{array}$ \\
\hline Cabbage & 6,000 & 30 & $1,80,000$ \\
\hline Cauliflower & 8,000 & 40 & $3,20,000$ \\
\hline Radish White & 2000 & 35 & 70,000 \\
\hline Bakula & 1,000 & 30 & 30,000 \\
\hline Mustard leaf & 5,500 & 40 & $2,20,000$ \\
\hline Spinach leaf & 2,000 & 45 & 90,000 \\
\hline Cress leaf & 2,000 & 45 & 90,000 \\
\hline \multicolumn{2}{|c|}{ Total: } & $\mathbf{2 6 , 5 0 0}$ & \multicolumn{1}{c}{} \\
\hline
\end{tabular}

Source: Field Survey, 2013. 


\section{MAJOR PROBLEMS AND PROSPECTS}

\section{MAJOR PROBLEMS OF VEGETABLE GARDENING}

In the agro-based economy like that of Nepal, the economic development is directly connected with agriculture development. The condition of agriculture in Nepal is poor. Nepalese agriculture is still suffering from multifarious problems.

In Nepal, more than 65 percent of people are involved in Agriculture which has significantly assisted to consolidate the economic conditions of the country. Among different food crops and cash crops, vegetables, the essential nutrients for the people, have been produced across the country in recent years as one of the vital income generating source. In Machchhegaun, too, people were actively engaged in this occupation. However, production was not satisfactory as expected due to multi-dimensional problems.

So far the problems facing by the farmers were concerned, out of total sampled households following numbers of respondents had pointed out the following problems in connection with vegetable cultivation (Table 5).

Table 5: Major Problems Identified by Vegetables Gardeners

\begin{tabular}{|l|c|c|}
\hline \multicolumn{1}{|c|}{ Major Problems } & $\begin{array}{c}\text { Frequency of } \\
\text { Respondents }\end{array}$ & Percent \\
\hline Lack of technical knowledge & 52 & 21.1 \\
\hline Unavailability of agriculture inputs & 50 & 20.2 \\
\hline Irrigation problem & 45 & 18.2 \\
\hline Poverty & 30 & 12.1 \\
\hline Unavailability of agriculture equipment & 25 & 10.1 \\
\hline Transportation problem & 20 & 8.2 \\
\hline Unavailability of chemical fertilizer & 25 & 10.1 \\
\hline \multicolumn{1}{|c|}{ Total: } & $\mathbf{2 4 7}$ & $\mathbf{1 0 0}$ \\
\hline
\end{tabular}

Source: Field Survey, 2013.

Table 5 states the problems which the farmers of Machchhegaun were facing for vegetables production. Higher proportion of farmers (21.1\%) faced the problems of inadequacy of technical knowledge while according to them the least proportion of problem compared to others was transportation which was just 8.2 percent. Similarly, the people were also facing other problems like inadequacy of irrigation facility, agriculture 
input, capital, chemical fertilizer and agricultural equipments. Those problems were major barriers to the farmers to grow plenty of vegetables.

\section{Prospects of Vegetable GaRdening}

The prospects of vegetable cultivation basically depend upon two major factors: physical condition and demand. In the absence of suitable physical condition, no crops can be grown and developed successfully. Similarly, production makes no sense without demand. Therefore, these two major parameters should be analyzed in this context.

In terms of physical condition, Machchhegaun is suitable for vegetable cultivation. Topographically, it is surrounded by hills. The soil is rich for organic matter which can produce plenty of vegetables. Furthermore, the suitable climatic condition adds benefits to the farmers for ample production. The prospects of vegetable gardening in the study area can be listed as follows.

\section{Good Productivity of Land}

Machchhegaun is rich in lacustrine soil which is very much suitable for vegetable cultivation. The land can be cultivated throughout the year for multiple vegetable productions. In cyclic rotation, any type of vegetable- seasonal or off-seasonal can be grown. There could be drastic change in vegetable cultivation if farmers are provided essential technical supports from the government.

\section{Suitable Climate and Physical Condition}

Climate plays a key role in crop production. There should be climatic change according to species of crops. In Machchhegaun farmers were experiencing different climatic situations. As a result, they were able to produce different vegetables in different seasons. Physically, the place surrounded by hills is very suitable for vegetable production. Physical condition, fertile soil, suitable climate and irrigation facilities were the essential factors for higher vegetable production.

\section{Availability of Market}

Due to rapid urbanization, the population of Kathmandu valley has been increasing tremendously. The faster the population increases, the more the demand for goods. Accordingly, the amount of vegetable in the current production is not sufficient for the consumers. Therefore, the farmers need to produce more vegetables as per the market demand. Machchhegaun has not produced vegetables according to the consumers demand. 


\section{Source of Employment}

Unemployment is the most serious and burning problem of the country. This problem can best be solved if farming could be modernized technically. In this connection vegetable farming is a labour intensive occupation thereby provides more employment opportunities than other professions.

\section{CONCLUSION}

Farming in Nepal is labour intensive and it has been subsistence farming for a very long time. Agriculture has been the main source of people's livelihood in which vegetables plays role for the purposes of domestic consumption and income generation.

Machchhegaun, located in ward no. 7 of Kirtipur Municipalities, is one of the vegetable growing areas. Vegetable cultivation has played a significant role to uplift the social status of the farmers in this area. This area is suitable for vegetable production due to suitable climate, fertile land, good topography and market availability, people here can grow different types of vegetables throughout the year utilizing even the small area of land. Of the total cultivated land, nearly 6.9 percent land is occupied by vegetable farming. However, this yield is higher in comparison with the other production. That is to say, 37.1 percent of the total land is used for paddy production which produces $20000 \mathrm{kgs}$ of rice while $30000 \mathrm{kgs}$ of vegetable could be obtained from the least cultivated area. Mainly rice, wheat and maize were produced but their yields were not as good as vegetables. Their living standard is raised as compared to previous years. However, people are facing multiple problems. There lacks irrigation facility, modern techniques, training, chemical fertilizer and proper marketing. If these problems are solved appropriately in time, Machchhegaun definitely would be a farming area for vegetable production which can fulfill the requirements of vegetables of rapidly growing population of the Kathmandu valley.

\section{WORKS CITED}

Agusiabo, O.N. (1979). Vegetable Gardening. London: Million Education Ltd., p.1.

Annual Progress Report (2065/066). Lalitpur: Government of Nepal, Ministry of Agriculture and Cooperative Agriculture Development Directorate of Vegetable Development.

CBS, (2001). Population Census of Nepal. Kathmandu: Central Bureau of Statistics, National Planning Commission Secretariat. 
Ghimire, S.N. (1999). Socio-Economic Impacts of Commercial Vegetable Farming: A Case Study from Charaundi, Dhusa VDC of Dhading Districts. M.A. Thesis, submitted to Central Department of Economic, Kathmandu: T.U., Nepal.

Lamichhane, B.D. (1999). Impact of Credit on Vegetable Production: A Case Study of Khanikhola Area. M.A. Thesis, submitted to Central Department of Management, Kathmandu: T.U., Kirtipur, Nepal.

Sapkota, K. (2009). "Farmer's Choice and Farmer's Voice on the Use of Local Versus Modern Inputs in Peri-urban Agriculture in Kathmandu valley, Nepal." In Khanal, N.R., Koirala, H.L. (eds.). The Geographical Journal of Nepal. Vol.7. 